\title{
Synthesis, characterisation and methyl orange adsorption capacity of ferric oxide-biochar nano-composites derived from pulp and paper sludge
}

\author{
Nhamo Chaukura ${ }^{1} \cdot$ Edna C. Murimba $^{2} \cdot$ Willis Gwenzi $^{3}$
}

Received: 7 November 2015/ Accepted: 31 January 2016/Published online: 15 February 2016

(C) The Author(s) 2016. This article is published with open access at Springerlink.com

\begin{abstract}
A} \mathrm{Fe}_{2} \mathrm{O}_{3}$-biochar nano-composite $\left(\mathrm{Fe}_{2} \mathrm{O}_{3}-\mathrm{BC}\right)$ was prepared from $\mathrm{FeCl}_{3}$-impregnated pulp and paper sludge (PPS) by pyrolysis at $750{ }^{\circ} \mathrm{C}$. The characteristics and methyl orange (MO) adsorption capacity of $\mathrm{Fe}_{2} \mathrm{O}_{3}-\mathrm{BC}$ were compared to that of unactivated biochar (BC). X-ray diffraction (XRD) and scanning electron microscopy (SEM) confirmed the composite material was nano-sized. Fourier transform infrared (FTIR) spectroscopy revealed the presence of hydroxyl and aromatic groups on $\mathrm{BC}$ and on $\mathrm{Fe}_{2} \mathrm{O}_{3}-\mathrm{BC}$, but Brunauer-Emmett-Teller (BET) surface area and Barrett-Joyner-Halenda $(\mathrm{BJH})$ porosity were lower for $\mathrm{Fe}_{2} \mathrm{O}_{3}-\mathrm{BC}$ than BC. Despite the lower BET surface area and porosity of $\mathrm{Fe}_{2} \mathrm{O}_{3}-\mathrm{BC}$, its $\mathrm{MO}$ adsorption capacity was $52.79 \%$ higher than that of BC. The equilibrium adsorption data were best represented by the Freundlich model with a maximum adsorption capacity of $20.53 \mathrm{mg} \mathrm{g}^{-1}$ at $\mathrm{pH} 8$ and $30 \mathrm{~min}$ contact time. MO adsorption obeyed pseudo-second-order kinetics for both $\mathrm{BC}$ and $\mathrm{Fe}_{2} \mathrm{O}_{3}-\mathrm{BC}$ with $R^{2}$ values of 0.996 and 0.999 , respectively. Higher $\mathrm{MO}$ adsorption capacity for $\mathrm{Fe}_{2} \mathrm{O}_{3}-$ $\mathrm{BC}$ was attributed to the hybrid nature of the nano-composites; adsorption occurred on both biochar matrix and $\mathrm{Fe}_{2} \mathrm{O}_{3}$ nanocrystals. Gibbs free energy calculations
\end{abstract}

Nhamo Chaukura

nchaukura@gmail.com

1 Department of Polymer Technology and Engineering, Harare Institute of Technology, PO Box BE 277, Belvedere, Harare, Zimbabwe

2 Department of Chemistry, Bindura University of Science Education, P Bag 1020, Bindura, Zimbabwe

3 Department of Soil Science and Agricultural Engineering, University of Zimbabwe, P.O. Box MP167, Mount Pleasant, Harare, Zimbabwe confirmed the adsorption is energetically favourable and spontaneous with a high preference for adsorption on both adsorbents. The nano-composite can be used for the efficient removal of $\mathrm{MO}(>97 \%)$ from contaminated wastewater.

Keywords Adsorption - Dye · Isotherms - Kinetics · Pollution

\section{Introduction}

Dyes are widely used in textile, plastic, paper, food, and cosmetic industries. Dyed wastewater from industrial processes pose public and environmental risks such as aesthetic pollution due to their colour (Pathania et al. 2013), and breakdown to release potentially toxic, carcinogenic or mutagenic products such as benzidine, naphthalene and other aromatic compounds (Bhatt et al. 2012; Belaid et al. 2013; Haldorai and Shim 2014; Mittal and Mishra 2014). Discharge of dyed wastewater into aquatic systems reduces light penetration and hence the photosynthetic activity of aquatic plants (Subasioglu and Bilkay 2009: Said et al. 2013). Such polluted water can also be a breeding ground for bacteria, viruses and vectors causing water-borne diseases. In addition, most dyes persist in the environment creating serious public health problems (Jain and Sikarwar 2008; Ma et al. 2012; Mittal and Mishra 2014). For example, methyl orange, an acidic anionic monoazodye (Bhatnagar and Jain 2005; Haque et al. 2011; Mahmoodian et al. 2015) commonly used in laboratory experiments, textiles and other commercial products, is toxic to aquatic life (Chung et al. 1981). Acute exposure can cause increased heart rate, vomiting, shock, cyanosis, jaundice, quadriplegia, and tissue necrosis in humans (Azami et al. 2012; Gong et al. 2013). 
Conventional treatment processes are not very effective in treating dyes in wastewater (Said et al. 2013). The use of natural and synthetic adsorbents is an attractive and effective alternative technique for the removal of dyes from contaminated water and is relatively cheap compared to other treatment methods (Crini 2006; Gadd 2009; Goscianska et al. 2014: Mittal and Mishra 2014). Earlier studies have shown that non-activated biowastes such as agro-processing wastes may be used as adsorbents (Amuda et al. 2007; Mohan and Pittman 2007; Osman et al. 2010; Pellera et al. 2011; Rita 2012; Mohan et al. 2014). The adsorption capacity of such biomaterials can be enhanced through physical or chemical activation.

Biochar is one emerging adsorbent formed via pyrolysis of biomaterials. Biochar has both high internal surface area and microporosity, and can be used as an adsorbent in separation and purification processes for gases, liquids, and colloidal solids (Zhang et al. 2013a, b; Alslaibi et al. 2014; Gwenzi et al. 2014). The large surface area and cation or anion exchange capacity, determined to a large extent by feedstocks and pyrolysis conditions, enable enhanced sorption of both organic and inorganic contaminants to biochar surfaces. Although biochar has been reported to effectively remove cationic species, other studies (Wang et al. 2015) show that it has relatively low adsorption capacity for anions. One option to enhance anion adsorption capacity is to develop hybrid adsorbents incorporating a biochar matrix and metal oxide crystals. Metal oxidebiochar nano-composites represent an emerging group of adsorbents for removal of neutral and ionic contaminants in aqueous solutions. We tested the hypothesis that metal oxide-biochar nano-composites has higher adsorption capacity than biochar due to their hybrid nature comprising two solid phases (Zhang et al. 2012); a biochar matrix and nanocrystals of metal oxides, both of which contribute to adsorption of contaminants. Therefore, the objectives of the current study were: (1) to synthesise and characterise $\mathrm{Fe}_{2} \mathrm{O}_{3}$-biochar nano-composites; and (2) to evaluate their capacity to adsorb methyl orange dye using kinetic and equilibrium batch studies.

\section{Materials and methods}

\section{Paper and pulp sludge sample preparation and preparation of biochar and ferric oxide-biochar nano-composite}

Paper and pulp sludge (PPS) was obtained from an effluent tank at a paper mill in Zimbabwe. The sludge was stored at $4{ }^{\circ} \mathrm{C}$ so as to minimise microbiological activity that could degrade the sample. The sample was then dewatered using a sieve of diameter $180 \mathrm{~mm}$, air dried for 2 days and then oven dried to constant weight at $70{ }^{\circ} \mathrm{C}$ for $24 \mathrm{~h}$. Two adsorbents were prepared in this study; (1) biochar (BC), and (2) $\mathrm{Fe}_{2} \mathrm{O}_{3}$-biochar $\left(\mathrm{Fe}_{2} \mathrm{O}_{3}-\mathrm{BC}\right)$. $\mathrm{BC}$ was prepared by pyrolysis of dried PPS at $750{ }^{\circ} \mathrm{C}$ for $2 \mathrm{~h}$ following procedures reported in earlier studies (Alslaibi et al. 2014; Gwenzi et al. 2014). $\mathrm{Fe}_{2} \mathrm{O}_{3}-\mathrm{BC}$ was synthesised by pyrolysis of $\mathrm{FeCl}_{3}$-impregnated PPS $(1: 3, \mathrm{~m} / \mathrm{v})$ at $750{ }^{\circ} \mathrm{C}$ for $2 \mathrm{~h}$ in a one-step pyrolysis method (Zhang et al. 2013a, b). The resulting materials were ground and sieved through a $250 \mu \mathrm{m}$ sieve and stored in closed containers prior to use.

\section{Characterisation of biochar and the nano-composite}

\section{Physico-chemical properties of adsorbents}

pH and EC were measured by pH (Adwa, 1020, Hungary) and EC (Thermofischer, Orion StarA212, Singapore) meters, respectively, on a sample $(0.25 \mathrm{~g})$ dispersed in deionised water $(50 \mathrm{~mL})$ and shaken for $30 \mathrm{~min}$. Moisture was determined gravimetrically by oven drying $1 \mathrm{~g}$ of each adsorbent at $105{ }^{\circ} \mathrm{C}$ for $12 \mathrm{~h}$. Ash content was determined by igniting $1 \mathrm{~g}$ of oven dried samples of each adsorbent at $600{ }^{\circ} \mathrm{C}$ for $2 \mathrm{~h}$. The point of zero charge $\left(\mathrm{pH}_{\mathrm{pzc}}\right)$ was determined by the $\mathrm{pH}$ drift method (Al-Degs et al. 2008). Briefly, for each adsorbent material, $0.1 \mathrm{~g}$ was mixed with $5 \mathrm{~mL} 0.01 \mathrm{M} \mathrm{NaCl}$ solution and $\mathrm{pH}$ adjusted between 1 and 12 using $0.01 \mathrm{M} \mathrm{HCl}$ and $0.01 \mathrm{M} \mathrm{NaOH}$. The mixture was left at room temperature for $48 \mathrm{~h}$ after which the $\mathrm{pH}$ of each suspension was measured.

\section{Functional groups, morphology and BET surface area}

Infrared spectra were recorded using a FTIR spectrometer (Thermofischer, Nicolet iS5, USA). A total of eight scans were carried out for each sample in the range 4000$400 \mathrm{~cm}^{-1}$ with a resolution of $4 \mathrm{~cm}^{-1}$. A diffractometer (PANalytical X'Pert Pro powder) ( $\mathrm{Cu} \mathrm{K} \alpha$ radiation with $\lambda=1.5406 \AA$ ) equipped with a PSD Lynx-Eye Si-strip detector with 196 channels, in a locked couple mode with an accelerating voltage of $40 \mathrm{kV}$ and an applied current of $40 \mathrm{~mA}$, was used to collect X-ray diffractograms for the samples at room temperature (Vala and Tichagwa 2013). BET surface area $\left(\mathrm{S}_{\mathrm{BET}}\right)$, pore volume and pore size were determined using an automated $\mathrm{N}_{2}$ adsorption analyser (TriStar 3000 V6.08 A, Micromeritics, Norcross, USA). SEM micrographs were obtained using a scanning electron microscope (Tescan, Vega3, Czech Republic) coupled to an energy dispersive X-ray spectroscopy (EDS) facility. The crystallite size, $L(\mathrm{~nm})$ was determined according to the Debye-Scherrer equation (Eq. 1) (Holzwarth and Gibson 2011): 
$L=\frac{K \lambda}{\beta \cos \theta}$

where $K$ is a constant with the value $0.89, \lambda$ is the characteristic wavelength of the X-ray source, $\beta$ is the full width at half maximum (FWHM) and $\theta$ is the angle diffraction.

\section{Batch adsorption experiments}

The effects of initial $\mathrm{pH}$, contact time, adsorbent dosage and initial dye concentration were investigated at $298 \mathrm{~K}$ using $50 \mathrm{mg}$ of each adsorbent except for adsorbent dosage experiments where various amounts were used. In all cases residual concentrations of $\mathrm{MO}$ after equilibration were measured at $500 \mathrm{~nm}$ wavelength using UV/Visible spectrophotometer (Shimadzu, 1800 Series, Tokyo) (Subasioglu and Bilkay 2009).

The effect of initial solution $\mathrm{pH}$ on $\mathrm{MO}$ removal was investigated on $\mathrm{pH} \mathrm{2,4,5,8,10}$ and 12 . The adsorbent material was agitated for $30 \mathrm{~min}$ with $20 \mathrm{~mL}$ of $50 \mathrm{mg} \mathrm{L}^{-1}$ MO solutions. The $\mathrm{pH}$ was adjusted using either $0.01 \mathrm{M}$ $\mathrm{NaOH}$ or $0.01 \mathrm{M} \mathrm{HCl}$. The effect of contact time on $\mathrm{MO}$ removal was studied using $20 \mathrm{~mL}$ of $50 \mathrm{mg} \mathrm{L}^{-1} \mathrm{MO}$ solution agitated with adsorbent for different contact times $(0,15,30,45,60,75$, and $90 \mathrm{~min})$ at the optimum $\mathrm{pH}$. The effect of adsorbent dosage was studied by agitating $20 \mathrm{~mL}$ of $50 \mathrm{mg} \mathrm{L}^{-1} \mathrm{MO}$ solution with different doses of adsorbents $(2.5,5.0,7.5,10.0,12.5 \mathrm{~g})$ for $30 \mathrm{~min}$ at optimum $\mathrm{pH}$. The effect of initial dye concentration was studied using five initial solution concentrations $(50,100,150,200$, and $250 \mathrm{mg} \mathrm{L}^{-1}$ ) for each adsorbent at an optimum $\mathrm{pH}$ and sorbent dosage for each adsorbent.

\section{Adsorption isotherms}

Adsorption isotherms were determined by introducing 7.5 and $5.0 \mathrm{~g}$ of $\mathrm{BC}$ and $\mathrm{Fe}_{2} \mathrm{O}_{3}-\mathrm{BC}$, respectively, (as determined by the adsorbent dosage experiments) into $\mathrm{MO}$ dye solutions $(20 \mathrm{~mL})$ of same concentrations and temperature as described in batch experiments. The adsorption capacity of each dye on the various adsorbents was calculated using Eq. 2 (Macedo et al. 2006; Bhatt et al. 2012; Rahimi et al. 2015; Ruziwa et al. 2015):

$Q_{t}=\frac{C_{o}-C_{t}}{m} V$

where $Q_{t}$ is the adsorption capacity at time, $t\left(\mathrm{mg} \mathrm{g}^{-1}\right), C_{o}$ and $C_{t}$ are the initial and final concentration at time $t$ $\left(\mathrm{mg} \mathrm{L}^{-1}\right), V$ is the volume of the solution (L) and $m$ is the mass of the adsorbent $(\mathrm{g})$. When equilibrium is reached at time $t, Q_{t}$ and $C_{t}$ become $Q_{e}$ and $C_{e}$, respectively. All experiments were done in triplicate and data are presented as means and standard error of mean. Two linearised isotherm models were fitted to the data: Langmuir (Eq. 3) and Freundlich (Eq. 4) (Bhatt et al. 2012; Ruziwa et al. 2015):

$\frac{1}{Q_{e}}=\frac{1}{Q b C_{e}}+\frac{1}{Q}$

where $Q_{e}$ is the equilibrium adsorption capacity of the material, $C_{e}$ is the equilibrium concentration of the solute in solution. The value of $K$ is related to the adsorption capacity of the adsorbent (Rita 2012).

The linearised Freundlich adsorption model (Eq. 4) was also fitted to the adsorption data.

$\log Q_{e}=\log K+\frac{1}{n} \operatorname{Lg} C_{e}$

where $K$ and $n$ are constants related to the adsorption capacity of the adsorbent and favourability and capacity of the adsorbent/adsorbate system, sometimes called the adsorption intensity or surface heterogeneity, respectively.

\section{Adsorption kinetics}

To investigate adsorption kinetics of $\mathrm{MO}$ on $\mathrm{BC}$ and $\mathrm{Fe}_{2} \mathrm{O}_{3}-\mathrm{BC}$, batch experiments were conducted at $\mathrm{pH} 2$ and 12 , respectively, using $20 \mathrm{~mL}$ of $50 \mathrm{mg} \mathrm{L}^{-1}$ of $\mathrm{MO}$ at the optimum adsorbent dosage. The mixture was shaken in a sonicator for $0,15,30,45$ and $60 \mathrm{~min}$, at $298 \mathrm{~K}$. Two reaction kinetic models were fitted to the data: pseudo-firstorder (Eq. 5) and pseudo-second-order equations (Eq. 6) (Macedo et al. 2006; Ruziwa et al. 2015):

$\operatorname{Ln}\left(Q_{t}-Q_{e}\right)=\operatorname{Ln} Q_{e}+k_{1} t$

$\frac{t}{Q_{t}}=\frac{1}{k_{2} Q_{e}^{2}}+\frac{t}{Q_{e}}$

where $Q_{e}\left(\mathrm{mg} \mathrm{g}^{-1}\right)$ and $Q_{t}\left(\mathrm{mg} \mathrm{g}^{-1}\right)$ are adsorption capacities at equilibrium and at time $t$, respectively, $k_{l}\left(\mathrm{~L} \min ^{-1}\right)$ is pseudo-first-order rate constant, and $k_{2}\left(\mathrm{~g} \mathrm{mg}^{-1} \mathrm{~min}^{-1}\right)$ is pseudo-second-order rate constant.

\section{Gibbs free energy change}

Practical process applications require information on thermodynamic parameters including enthalpy change $\left(\Delta \mathrm{H}^{0}\right)$, entropy change $\left(\Delta S^{0}\right)$, and Gibbs free energy change $\left(\Delta \mathrm{G}^{0}\right) . \Delta \mathrm{G}^{0}$ indicates the characteristics of adsorption on biosorbents (Bhatt et al. 2012; Pathania et al. 2013). In this study, batch adsorption experiments were carried out at $298 \mathrm{~K}$, hence the value of $\Delta \mathrm{G}^{0}$ was estimated from Eq. 7 (Mittal et al. 2007; Chen et al. 2011; Kakavandi et al. 2013; Pavlović et al. 2014): 
$\Delta G^{0}=-\mathrm{R} T \operatorname{Ln} K$

where $K$ is Langmuir or Freundlich constant depending on the best fitting model for the data, $\mathrm{R}\left(8.314 \mathrm{~J} \mathrm{~mol}^{-1} \mathrm{~K}\right)$ is the universal gas constant, $T(\mathrm{~K})$ is absolute solution temperature.

\section{Results and discussion}

\section{Characterisation of adsorbents}

\section{Physico-chemical properties}

The $\mathrm{pH}$ values of PPS and $\mathrm{BC}$ were alkaline, while that of $\mathrm{Fe}_{2} \mathrm{O}_{3}-\mathrm{BC}$ was acidic (Table 1). PPS is treated to $\mathrm{pH}$ 6.5-7.5 before discharge into public waterways at the mill. The increased $\mathrm{pH}$ for $\mathrm{BC}$ can be attributed to the removal of volatiles in the biochar matrix during pyrolysis, which increased the $\mathrm{pH}$ of the biomass from 7.31 to 8.46 for $\mathrm{BC}$, while acidic $\mathrm{pH}$ of $\mathrm{Fe}_{2} \mathrm{O}_{3}-\mathrm{BC}$ could be due to impregnating the biomass with $\mathrm{FeCl}_{3}$ prior to pyrolysis. In aqueous solution, $\mathrm{Fe}^{3+}$ compounds undergo hydrolysis to produce $\mathrm{H}^{+}$ions. Similar results for biochar prepared without prior treatment have been obtained by Gwenzi et al. (2014). The electrical conductivity (EC) and the ash content for $\mathrm{Fe}_{2} \mathrm{O}_{3}-$ $\mathrm{BC}$ were higher than for $\mathrm{BC}$. Introducing $\mathrm{Fe}_{2} \mathrm{O}_{3}$ into the biochar matrix is expected to increase the content of soluble salts within the composite material.

$\mathrm{Fe}_{2} \mathrm{O}_{3}-\mathrm{BC}$ had $\mathrm{pH}_{\text {zpc }}$ of 2.1 , while $\mathrm{BC}$ had a higher $\mathrm{pH}_{\mathrm{zpc}}$ of 8.3, indicating that $\mathrm{BC}$ and $\mathrm{Fe}_{2} \mathrm{O}_{3}-\mathrm{BC}$ are predominantly positive at $\mathrm{pH}$ below 2.1 and 8.3 , respectively (Table 1). At $\mathrm{pH}>2.1$ the surface of $\mathrm{Fe}_{2} \mathrm{O}_{3}-\mathrm{BC}$ was negatively charged, thus disregarding the possibility of electrostatic attraction being a mechanism of removal of $\mathrm{MO}$ from solution. The positive charge on the surface of $\mathrm{BC}$ at $\mathrm{pH}$ values lower than 8 makes electrostatic attraction of the dye molecules to the surface a possible mechanism for the removal of MO at those $\mathrm{pH}$ values (Jalil et al. 2010). However, this mechanism does not seem to be very efficient since the maximum adsorption value is not very high $\left(15 \mathrm{mg} \mathrm{g}^{-1}\right)$ compared to values obtained for other adsorbents such as orange peel (Annadurai et al. 2002). Therefore, other mechanisms such as complexation may contribute to the removal of MO molecules in single solute solutions (Park et al. 2010; Rahimi et al. 2015).

The BET surface area $\left(\mathrm{S}_{\mathrm{BET}}\right)$, total pore volume and average pore diameter for $\mathrm{BC}$ and $\mathrm{Fe}_{2} \mathrm{O}_{3}-\mathrm{BC}$ were lower than those reported for other adsorbents (Khalili et al. 2000; Alslaibi et al. 2014). The reduced $\mathrm{S}_{\mathrm{BET}}$ in $\mathrm{Fe}_{2} \mathrm{O}_{3}-\mathrm{BC}$ could be attributed to the blocking of pores in the biochar matrix by $\mathrm{Fe}_{2} \mathrm{O}_{3}$ and other metal compounds inherent in the biosorbent. This is shown by the high ash content compared to 0.3 and $20.08 \%$ obtained for fruit pulp (Angulo-Bejarano et al. 2014) and mucilage (Espino-Díaz et al. 2010). Surface area and porosity constitute key parameters of adsorbents (Alslaibi et al. 2015). The average pore diameters of $\mathrm{BC}$ and $\mathrm{Fe}_{2} \mathrm{O}_{3}-\mathrm{BC}$ indicate the materials were both in the mesopore region. Similar results were obtained for activated carbon derived from olive stone (Alslaibi et al. 2014, 2015).

\section{FTIR spectra}

Both $\mathrm{BC}$ and $\mathrm{Fe}_{2} \mathrm{O}_{3}-\mathrm{BC}$ exhibited pronounced peaks in the $3300-3400 \mathrm{~cm}^{-1}$ region showing that the adsorbents contain the hydroxyl functional group (Fig. 1). This peak is due to the stretch of an inter-molecularly bonded $\mathrm{O}-\mathrm{H}$ and is typical for alcohols, phenolics and carboxylic functional groups present in cellulosic materials (Pathania et al. 2013). The peaks for $\mathrm{Fe}_{2} \mathrm{O}_{3}-\mathrm{BC}$ around $1590 \mathrm{~cm}^{-1}$ show the presence of a $\mathrm{C}=\mathrm{C}-\mathrm{C}$ stretch, which is characteristic of an aromatic ring stretch. In agreement with previous studies (e.g., Mittal and Mishra 2014), the characteristic $\mathrm{Fe}-\mathrm{O}$ bond appeared at $560 \mathrm{~cm}^{-1}$. BC has a characteristic peak at about $990-1000 \mathrm{~cm}^{-1}$ which is due to an alkene, $=\mathrm{C}-\mathrm{H}$ bend. The spectrum for $\mathrm{BC}$ showed no evidence of other oxygen containing groups in $\mathrm{BC}$, except for the hydroxyl group, showing that the material was highly carbonised. Raw biomass has been shown to have characteristic C-H stretch at $2820-2860 \mathrm{~cm}^{-1}$ which is typical of a $\mathrm{H}-\mathrm{C}=\mathrm{O}$ stretch in aldehydes due to cellulosic composition (Ciolacu et al. 2011). This peak is, however, not evident in the spectra of $\mathrm{BC}$ and $\mathrm{Fe}_{2} \mathrm{O}_{3}-\mathrm{BC}$, suggesting that it

Table 1 Physico-chemical properties of raw paper and pulp sludge (PPS), biochar (BC), and ferric oxide-biochar $\left(\mathrm{Fe}_{2} \mathrm{O}_{3}-\mathrm{BC}\right)$ nanocomposite

\begin{tabular}{llllllllll}
\hline Adsorbent & $\mathrm{pH}$ & $\begin{array}{l}\mathrm{EC} \\
\left(\mathrm{mS} \mathrm{m}{ }^{-1}\right)\end{array}$ & \% Moisture & $\%$ Ash & $\begin{array}{l}\mathrm{S}_{\mathrm{BET}} \\
\left(\mathrm{m}^{2} \mathrm{~g}^{-1}\right)\end{array}$ & $\begin{array}{l}\text { Pore volume } \\
\left(\mathrm{cm}^{3} \mathrm{~g}^{-1}\right)\end{array}$ & $\begin{array}{l}\text { Pore diameter } \\
(\mathrm{nm})\end{array}$ & $\mathrm{pHzpc}$ & $\%$ Fe \\
\hline $\mathrm{PPS}$ & $7.31 \pm 0.09$ & $0.163 \pm 0.016$ & $5.83 \pm 0.33$ & $11.0 \pm 0.2$ & - & - & - & - & - \\
$\mathrm{BC}$ & $8.46 \pm 0.02$ & $0.162 \pm 0.001$ & $1.40 \pm 0.03$ & $36.2 \pm 1.3$ & $174 \pm 5$ & $40.0 \pm 2.1$ & $1.7-300$ & $8.3 \pm 0.2$ & $0.3 \pm 0.04$ \\
$\mathrm{Fe}_{2} \mathrm{O}_{3}-\mathrm{BC}$ & $2.86 \pm 0.01$ & $5.330 \pm 0.180$ & $11.80 \pm 0.92$ & $49.3 \pm 0.4$ & $15.3 \pm 0.1$ & $3.5 \pm 0.1$ & $1.7-300$ & $2.1 \pm 0.1$ & $22.6 \pm 1.4$ \\
\hline
\end{tabular}

Data are presented as mean $\pm \operatorname{SEM}(n=3)$ 
Fig. 1 FTIR spectra for $\mathrm{BC}$ and $\mathrm{Fe}_{2} \mathrm{O}_{3}-\mathrm{BC}$

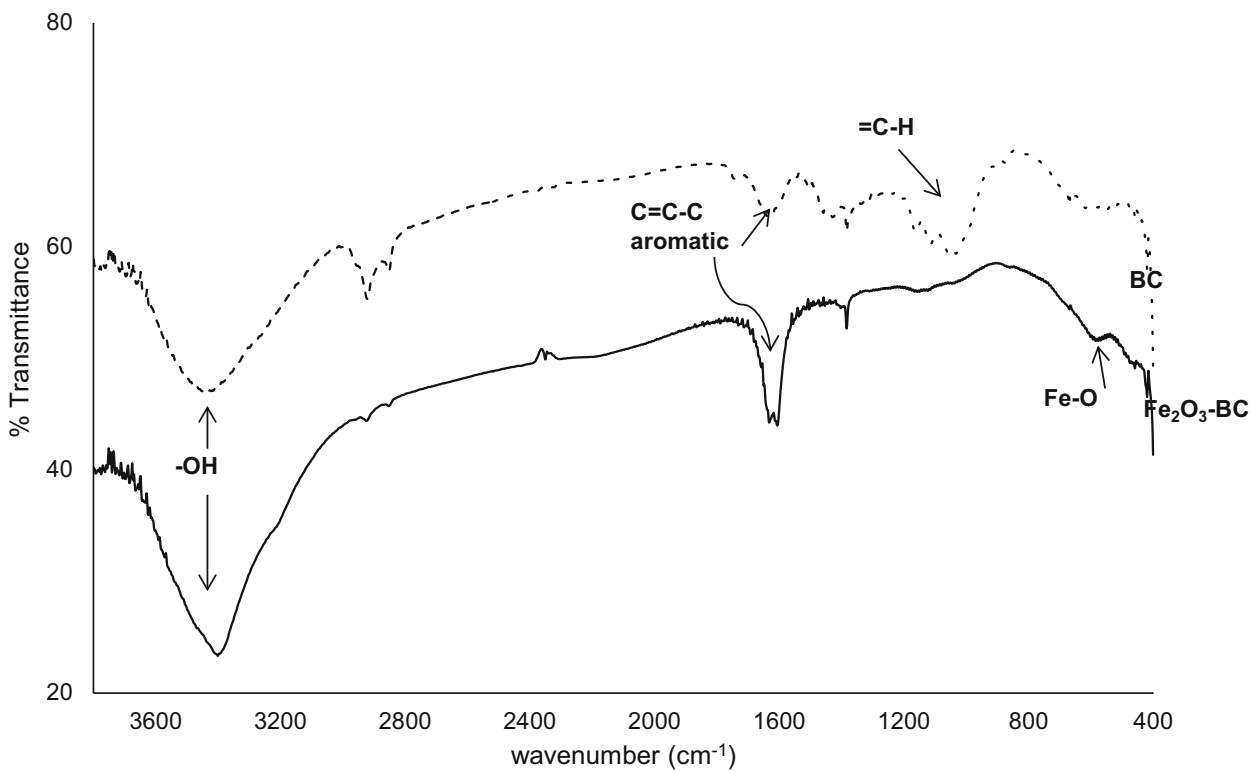

could have been modified or introduced during pyrolysis (Macedo et al. 2006). MO being cationic is likely to form strong ionic interactions with the hydroxyl, carboxylic functional groups (Pathania et al. 2013) and also with the electron dense double bonds in addition to dative bonds within the biosorbents. Being a planar molecule, MO can have $\pi-\pi$ stacking interactions between the aromatic moiety of the dye and the hexagonal framework of $\mathrm{BC}$ and $\mathrm{Fe}_{2} \mathrm{O}_{3}-\mathrm{BC}$ (Gong et al. 2013; Zhang et al. 2013a, b).

\section{SEM-EDS analysis}

The micrograph (Fig. 2b) shows heterogeneous particles, which confers porosity to the material making it suitable for MO adsorption (Pathania et al. 2013). Despite the heterogeneity, the images suggest the material is a nanocomposite with some of the particles measured on the micrographs in the order of tens of nanometers (i.e. $55 \mathrm{~nm}$ ). The SEM-EDS spectra show that there is a higher amount of $\mathrm{Fe}$ in the $\mathrm{Fe}_{2} \mathrm{O}_{3}-\mathrm{BC}(22.4 \%)$ than the $\mathrm{BC}$ $(0.3 \%)$ (Fig. 2), which is consistent with XRD results (Fig. 3). This suggests that $\mathrm{Fe}_{2} \mathrm{O}_{3}$ was successfully incorporated on the biochar matrix as nanocrystals. Other elements present in both samples in lesser amounts are $\mathrm{Al}, \mathrm{Ca}$, $\mathrm{O}, \mathrm{Mn}, \mathrm{Cl}$ and $\mathrm{Si}$. There is a possibility that these elements and their compounds could have contributed to adsorption. Their effect could, however, have been minimised by leaching them out before adsorption.

\section{$X R D$ analysis}

XRD analysis was performed to confirm successful incorporation of $\mathrm{Fe}_{2} \mathrm{O}_{3}$ within the biochar matrix and estimate crystallite sizes and $d$-spacing. The XRD pattern of $\mathrm{BC}$ showed diffraction peaks at $2 \theta$ values of $26^{\circ}, 28^{\circ}, 39^{\circ}, 43^{\circ}$ and $47^{\circ}$ (Fig. 3a). All these peaks were also found in the XRD pattern for $\mathrm{Fe}_{2} \mathrm{O}_{3}-\mathrm{BC}$ nano-composites (Fig. 3b) although at lower intensities, which confirmed the incorporation of $\mathrm{Fe}_{2} \mathrm{O}_{3}$ in the nano-composite. Peaks at $31^{\circ}, 43^{\circ}$ and $57^{\circ}$ have been indexed for maghemite, a Fe compound (Zhang et al. 2013a, b).

Using XRD software that takes instrumental peak broadening into account (Feng et al. 2003), the most intense peaks were used as references $\left(2 \theta=29.4\right.$ and $16.0^{\circ}$ for $\mathrm{BC}$ and $\mathrm{Fe}_{2} \mathrm{O}_{3}-\mathrm{BC}$, respectively) to calculate values of crystal sizes of the materials. This gave $L$ and $d$-spacing values for $\mathrm{BC}$ and $\mathrm{Fe}_{2} \mathrm{O}_{3}-\mathrm{BC}$ as $1.33-58 \mathrm{~nm}, 1.27-10 \mathrm{~nm}$ and 3.04 and $5.53 \AA$, respectively (Zhan et al. 2010), confirming the materials were nano-scale, with $\mathrm{Fe}_{2} \mathrm{O}_{3}-\mathrm{BC}$ being made up of a narrower range of particles.

\section{BET surface area and porosity}

The BET surface area of BC $\left(174.29 \mathrm{~m}^{2} \mathrm{~g}^{-1}\right)$ is an order of magnitude higher than that of $\mathrm{Fe}_{2} \mathrm{O}_{3}-\mathrm{BC}\left(15.32 \mathrm{~m}^{2} \mathrm{~g}^{-1}\right)$, suggesting that the surface area is reduced by $\mathrm{Fe}_{2} \mathrm{O}_{3}$ taking up the interstitial pores in the biochar matrix.

The shapes of the $\mathrm{N}_{2}$ isotherms exhibit hysteresis showing that the adsorption of the molecules is irreversible (Fig. 4a). The hysteresis loop is characteristic of nanoporous materials with a narrow distribution of pore sizes (Chaukura 2011). The BJH pores size distribution (Fig. 4b) shows that the pores of both materials, $\mathrm{Fe}_{2} \mathrm{O}_{3}-\mathrm{BC}$ and $\mathrm{BC}$, span the nano-region $(1.7-300 \mathrm{~nm})$, and the micro, meso and macroporous regions. The molecular size of MO is $1.31 \times 0.55 \times 0.18 \mathrm{~nm}^{3}$ (Goscianska et al. 2014), and it 
Fig. 2 SEM micrographs (left) for $\mathrm{BC}$ (a) and $\mathrm{Fe}_{2} \mathrm{O}_{3}-\mathrm{BC}$ (b) and corresponding SEMEDS (right)
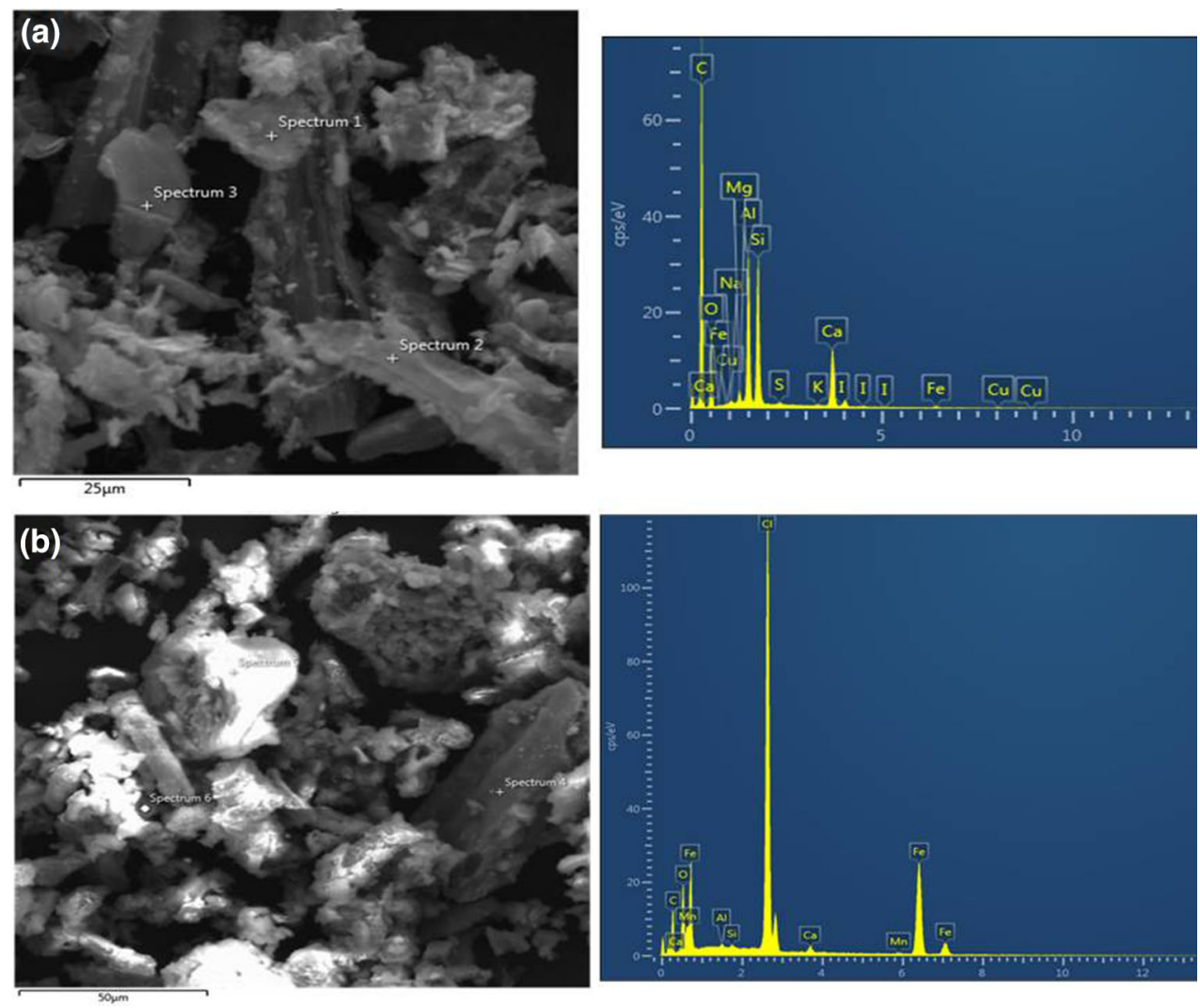

can fit into the average pores of the $\mathrm{BC}$ and $\mathrm{Fe}_{2} \mathrm{O}_{3}-\mathrm{BC}$ adsorbents during the adsorption. Although the $\mathrm{S}_{\mathrm{BET}}$ of the adsorbents after adsorption was not measured, earlier studies have shown that after adsorption the $\mathrm{S}_{\mathrm{BET}}$ of adsorbents will decrease due to dye molecules occupying the pores in the biosorbents framework (Zhuang et al. 2009).

\section{Effect of experimental parameters}

\section{Effect of initial solution $\mathrm{pH}$}

$\mathrm{BC}$ showed a higher adsorption $\left(15 \mathrm{mg} \mathrm{g}^{-1}\right)$ at $\mathrm{pH} 2$, while $\mathrm{Fe}_{2} \mathrm{O}_{3}-\mathrm{BC}$ had greatest adsorption at $\mathrm{pH} 12\left(20 \mathrm{mg} \mathrm{g}^{-1}\right)$ (Fig. 5a). The adsorption of dye molecules is $\mathrm{pH}$ dependent. Due to the dissociation of the $\mathrm{Na}^{+}$ion, the $\mathrm{MO}$ molecule exists as an anion in aqueous solution around and above $\mathrm{pH}$ 7. Under acidic conditions, the $\mathrm{H}^{+}$ion would be attached to the nitrogen atom of azo group resulting in the formation of amphoteric methyl orange molecules (Akama et al. 1999). Adjusting pH below 3 results in the methyl orange dye changing from orange to pink colour, showing that $\mathrm{pH}$ influences the ionisation of methyl orange (Ma et al. 2012). For both adsorbents, an increase in $\mathrm{pH}$ above pH 2 led to decreased adsorption. For $\mathrm{Fe}_{2} \mathrm{O}_{3}-\mathrm{BC}$ the adsorption increased again after $\mathrm{pH} 9$ before peaking at $\mathrm{pH}$
12. Generally, an increase in $\mathrm{pH}$ is expected to reduce the adsorption of acidic dyes (Park et al. 2010). That adsorption onto $\mathrm{Fe}_{2} \mathrm{O}_{3}-\mathrm{BC}$ is high at alkaline $\mathrm{pH}$ could suggest another overriding adsorption mechanism, for example complexation. Another possibility is that the high inherent $\mathrm{H}^{+}$as indicated by highly acidic $\mathrm{pH}$ of the $\mathrm{Fe}_{2} \mathrm{O}_{3}-\mathrm{BC}$ results in base neutralisation and $\mathrm{pH}$ buffering.

\section{Effect of contact time}

Adsorption of MO was generally rapid for the first $15 \mathrm{~min}$, after which it slowed down and flattened off as contact time increased (Fig. 5b). This is explained by the fact that, initially, adsorption sites are vacant and the dye concentration is high, but after about $15 \mathrm{~min}$ the population of adsorption sites dwindles along with the concentration gradient (Belaid et al. 2013; Pathania et al. 2013). The slowing down of adsorption could be due to possible formation of a monolayer on the adsorbent surface caused in turn by the aforementioned unavailability of adsorption sites after equilibrium is attained (Abd et al. 2009; Liang et al. 2010; Park et al. 2010). Barka et al. (2013) reported similar results for the adsorption of cadmium and lead onto dried cactus. The short adsorption time could possibly be a result of the limited porous nature of the adsorbents which would result in external adsorption as reported by Rahimi 


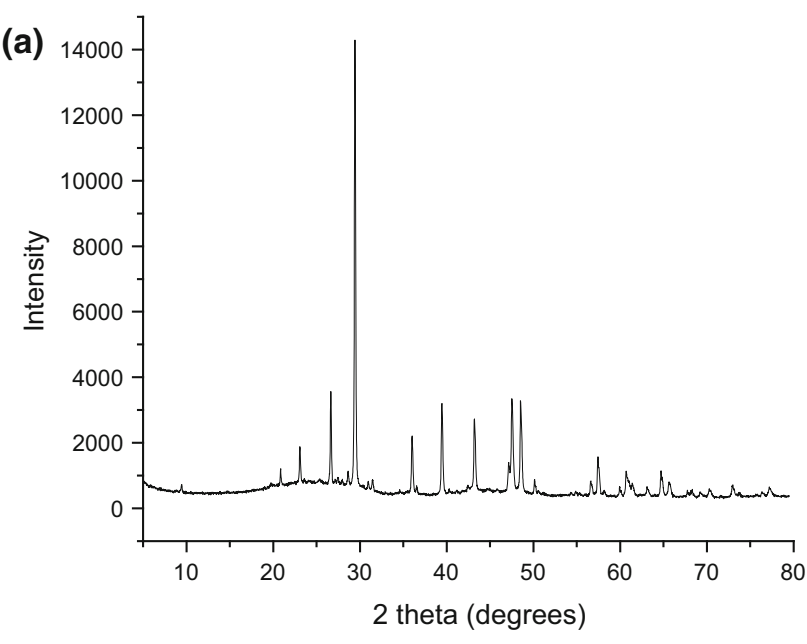

(b)

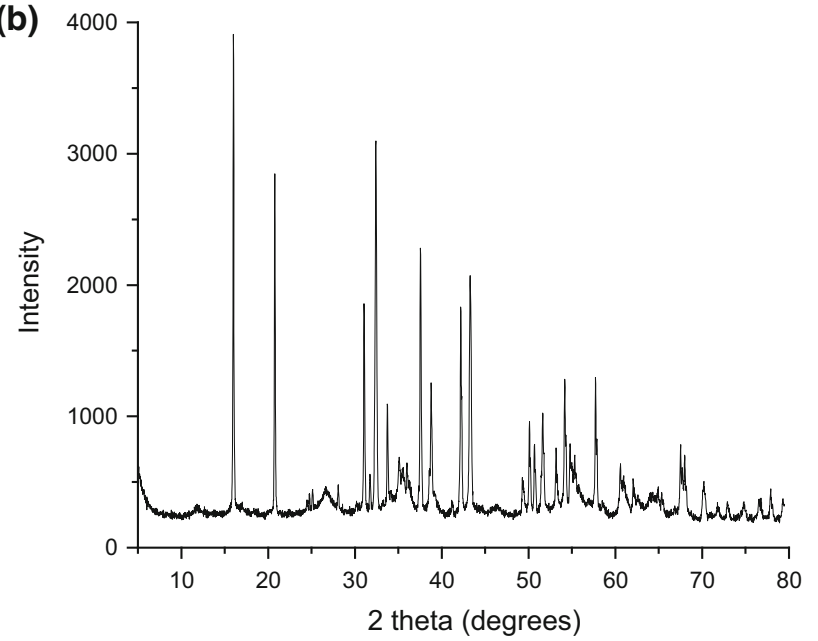

Fig. 3 XRD diffractograms for a $\mathrm{BC}$ and $\mathbf{b} \mathrm{Fe}_{2} \mathrm{O}_{3}-\mathrm{BC}$

et al. (2015). In addition, the small size of the $\mathrm{Fe}_{2} \mathrm{O}_{3}$ nanoparticles in $\mathrm{Fe}_{2} \mathrm{O}_{3}-\mathrm{BC}$ facilitates efficient dispersion into the bulk solution increasing the population of sites available for adsorption (Rahimi et al. 2015). The MO molecules encounter the boundary layer effect before diffusing from the boundary layer film onto the adsorbent surface followed by the diffusion into the porous structure of the adsorbent which takes relatively longer contact time. Consequently, the time profile of the dye adsorption by the adsorbent is a smooth and continuous curve culminating in a saturation $Q_{e}$ value (Khattri and Singh 2009). $\mathrm{Fe}_{2} \mathrm{O}_{3}-\mathrm{BC}$ had higher MO adsorption capacity than $\mathrm{BC}$ under the experimental conditions (Fig. 5b) indicating that the activation was effective.

\section{Effect of adsorbent dosage}

Since the optimum $\mathrm{pH}$ values for the adsorbents were 2 and 12 for $\mathrm{BC}$ and $\mathrm{Fe}_{2} \mathrm{O}_{3}-\mathrm{BC}$, respectively, all subsequent experiments were carried out at these $\mathrm{pH}$ values. Increasing the adsorbent mass from 2.5 up to $12.5 \mathrm{~g} \mathrm{~L}^{-1}$ was accompanied by an increase in the percentage removal of $\mathrm{MO}$ (Fig. 5c). Both $\mathrm{BC}$ and $\mathrm{Fe}_{2} \mathrm{O}_{3}-\mathrm{BC}$ achieved $100 \%$ removal of $\mathrm{MO}$ at $5 \mathrm{~g} \mathrm{~L}^{-1}$ adsorbent dosage. There was a slight decrease in removal efficiency after $5 \mathrm{~g} \mathrm{~L}^{-1}$ adsorbent dosage. This could be due to aggregation of adsorbent and a consequent decrease in surface area (Subasioglu and Bilkay 2009; Barka et al. 2013; Pathania et al. 2013).

\section{Effect of initial dye concentration}

$\mathrm{Fe}_{2} \mathrm{O}_{3}-\mathrm{BC}$ had a $100 \%$ removal at $50 \mathrm{mg} \mathrm{L}^{-1}$, which reduced slightly to $97 \%$ with an increase in initial concentration, $C_{o}$ up to $250 \mathrm{mg} \mathrm{L}^{-1}$ (Fig. 5d). The adsorption capacity of the adsorbent increased from 10 to $46 \mathrm{mg} \mathrm{g}^{-1}$ as the initial concentrations increased. BC also had $100 \%$ removal from solution with an initial MO concentration of $50 \mathrm{mg} \mathrm{L}^{-1}$. The binding sites for biosorbents saturate with increasing dye concentration (Subasioglu and Bilkay 2009). $\mathrm{Fe}_{2} \mathrm{O}_{3}-\mathrm{BC}$ consistently gave higher adsorption capacities compared to $\mathrm{BC}$, suggesting that the mechanism
Fig. 4 a $\mathrm{N}_{2}$ adsorption and desorption isotherms for $\mathrm{BC}$ and $\mathrm{Fe}_{2} \mathrm{O}_{3}-\mathrm{BC}$, and $\mathbf{b} \mathrm{BJH}$ pore size distribution for $\mathrm{BC}$ and $\mathrm{Fe}_{2} \mathrm{O}_{3}-$ $\mathrm{BC}$

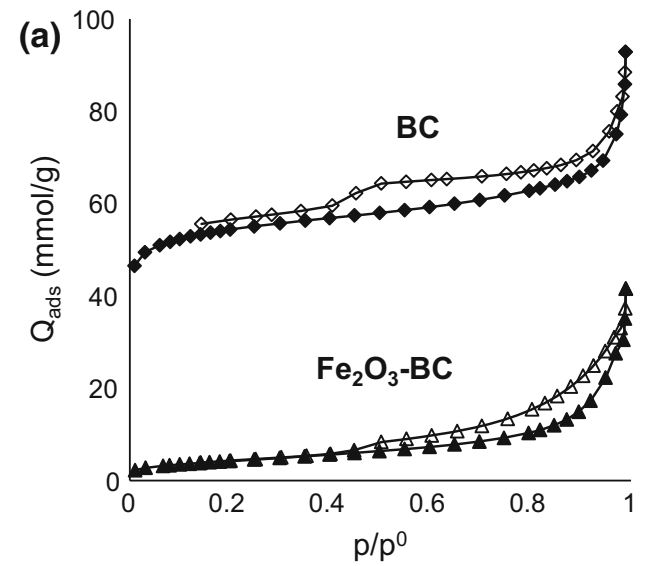

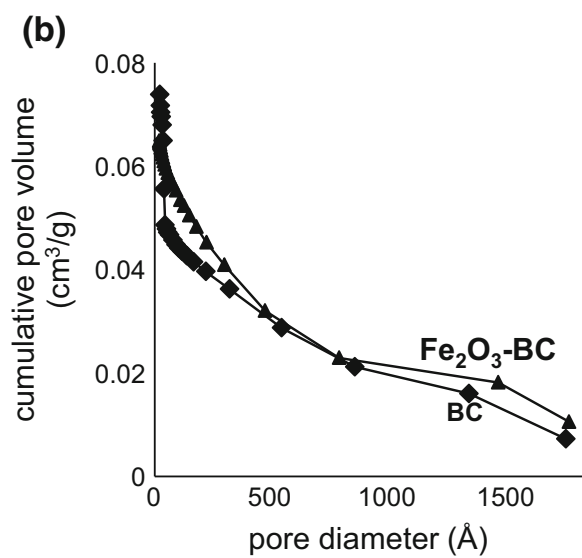

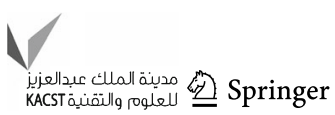


Fig. 5 Effect of a initial solution $\mathrm{pH}, \mathbf{b}$ contact time, c sorbent dosage, and $\mathbf{d}$ initial MO concentration on the adsorption effectiveness for methyl orange on $\mathrm{BC}$ (open diamond) and $\mathrm{Fe}_{2} \mathrm{O}_{3}-\mathrm{BC}$ (filled diamond). Error bars indicate standard error of the mean (a)

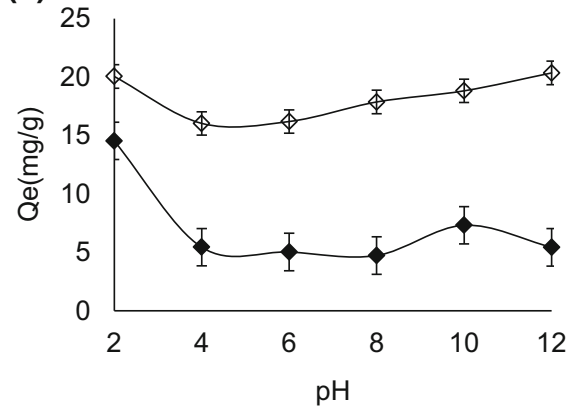

(c)

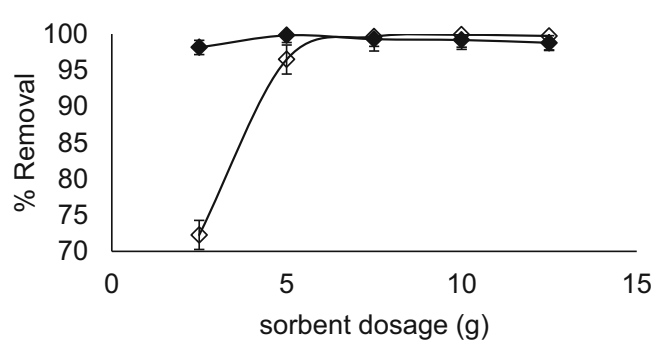

(b) 25

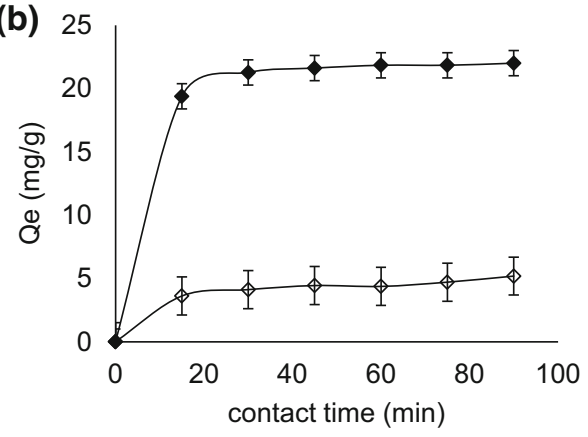

(d)

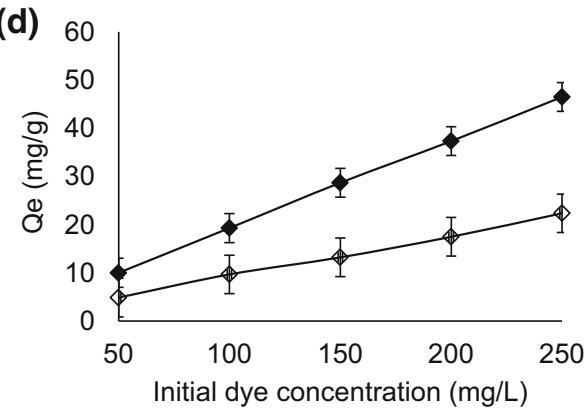

by which the material is removing dyes from solution is enhanced by the presence of $\mathrm{Fe}$ in the material. The metal possibly forms dative bonds with the heteroatoms within the dye molecules (Park et al. 2010). The $\mathrm{S}$ atom present in the molecular structure of $\mathrm{MO}$ is a soft acid and strong ligand (Gadd 2009). An increase in initial dye concentration increases the chances of interaction between the dye and the adsorbent, thus enhancing the dye uptake (Park et al. 2010).

\section{Adsorption isotherms}

Methyl orange adsorption by $\mathrm{Fe}_{2} \mathrm{O}_{3}-\mathrm{BC}$ followed Langmuir model reasonably well $\left(R^{2}=0.8886\right)$ (Fig. 6a). Adsorption by $\mathrm{BC}$ and by $\mathrm{Fe}_{2} \mathrm{O}_{3}-\mathrm{BC}$ had comparable $Q$ and $K$ values (Table 2) for the Langmuir model. However, the model does not adequately explain the adsorption of the dye on the BC adsorbent $\left(R^{2}=0.5349\right)$. A comparison of the $R^{2}$ values of the two models shows that the Freundlich model fits better the adsorption of MO onto $\mathrm{Fe}_{2} \mathrm{O}_{3}-\mathrm{BC}$ than the Langmuir model (Fig. 6b). For the adsorption of $\mathrm{MO}$ on $\mathrm{BC}$ the Freundlich model has a better fit $\left(R^{2}=0.7283\right)$ than the Langmuir model.

The experimental values of $K$ obtained using the linearised Freundlich equation (Eq. 3) suggest that the adsorbents $\mathrm{BC}$ and $\mathrm{Fe}_{2} \mathrm{O}_{3}-\mathrm{BC}$ have high adsorption capacities for MO (Table 2). The magnitude of $n$ gives an indication of the favourability and capacity of the adsorbent/adsorbate system, sometimes called the adsorption intensity or surface heterogeneity (Sun et al. 2013). Values where $n>1$ represent favourable adsorption conditions and that the adsorption is a physical process (Meroufel et al. 2013; Ruziwa et al. 2015). It follows that MO adsorption was favourable on both adsorbents.

\section{Adsorption kinetics}

The $R^{2}$ values for the pseudo-second-order kinetic model for both $\mathrm{Fe}_{2} \mathrm{O}_{3}-\mathrm{BC}$ and $\mathrm{BC}$ were higher and very close to unity $\left(0.9960 \leq R^{2} \leq 0.9999\right)$ compared to the pseudofirst-order model $\left(0.8109 \leq R^{2} \leq 0.9438\right)$. This result suggests that the adsorption behaviour followed pseudosecond-order model and it indicates the rate-determining step may be chemisorption (Valderrama et al. 2010). Chemisorption involves strong attractive forces due to exchanging of electrons (Bhattacharyya and Sharma 2005) (Fig. 7).

A comparison of $\mathrm{BC}$ and $\mathrm{Fe}_{2} \mathrm{O}_{3}-\mathrm{BC}$ with other adsorbents (Table 3) shows that $\mathrm{BC}$ and $\mathrm{Fe}_{2} \mathrm{O}_{3}-\mathrm{BC}$ have higher $Q_{e}$ values than either of coconut dust activated carbon (coconut dust AC) or Humicola fuscoatra biomass.

\section{Free energy of adsorption}

Gibbs free energy values calculated from Eq. 7 were -5.932 and $-7.344 \mathrm{~kJ} \mathrm{~mol}^{-1}$ for $\mathrm{BC}$ and $\mathrm{Fe}_{2} \mathrm{O}_{3}-\mathrm{BC}$ 
Fig. 6 Langmuir (a) and Freundlich (b) adsorption isotherms for methyl orange on $\mathrm{BC}$ (open diamond) and $\mathrm{Fe}_{2} \mathrm{O}_{3}-$ $\mathrm{BC}$ (filled diamond). Error bars indicate standard error of the mean

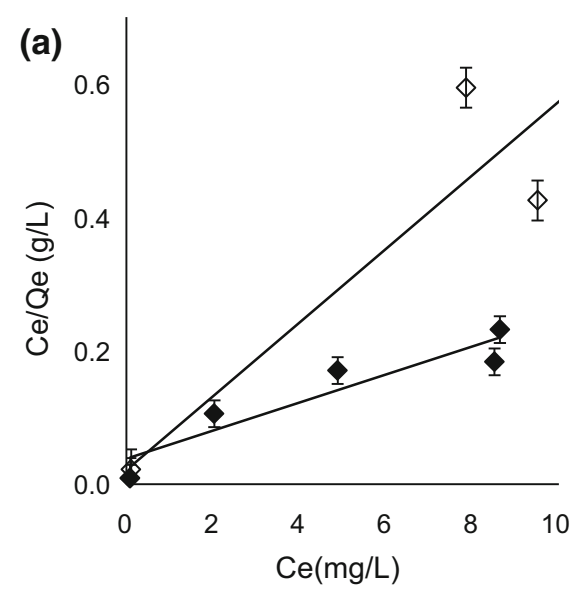

Table 2 Best-fit parameters for isotherm and kinetic models for $\mathrm{BC}$ and $\mathrm{Fe}_{2} \mathrm{O}_{3}-\mathrm{BC}$

\begin{tabular}{|c|c|c|c|c|}
\hline Adsorbent & Model & Parameter 1 & Parameter 2 & $R^{2}$ \\
\hline \multirow[t]{4}{*}{$\mathrm{BC}$} & Langmuir & $K=7.60 \mathrm{~L} \mathrm{mg}^{-1}$ & $Q=16.05 \mathrm{mg} \mathrm{g}^{-1}$ & 0.5349 \\
\hline & Freundlich & $K=10.96 \mathrm{mg} \mathrm{g}^{-1}$ & $n=5.07$ & 0.7238 \\
\hline & 1st order & $k_{1}=0.03 \mathrm{~L} \mathrm{~min}^{-1}$ & $Q_{e}=3.20 \mathrm{mg} \mathrm{g}^{-1}$ & 0.8109 \\
\hline & 2nd order & $k_{2}=32.50 \mathrm{~g} \mathrm{mg}^{-1} \mathrm{~min}^{-1}$ & $Q_{e}=2.69 \mathrm{mg} \mathrm{g}^{-1}$ & 0.9960 \\
\hline \multirow[t]{4}{*}{$\mathrm{Fe}_{2} \mathrm{O}_{3}-\mathrm{BC}$} & Langmuir & $K=5.46 \mathrm{~L} \mathrm{mg}^{-1}$ & $Q=16.05 \mathrm{mg} \mathrm{g}^{-1}$ & 0.8886 \\
\hline & Freundlich & $K=19.38 \mathrm{mg} \mathrm{g}^{-1}$ & $n=3.30$ & 0.9229 \\
\hline & 1st order & $k_{1}=0.08 \mathrm{~L} \mathrm{~min}^{-1}$ & $Q_{e}=12.64 \mathrm{mg} \mathrm{g}^{-1}$ & 0.9414 \\
\hline & 2nd order & $k_{2}=12427.39 \mathrm{~g} \mathrm{mg}^{-1} \mathrm{~min}^{-1}$ & $Q_{e}=23.75 \mathrm{mg} \mathrm{g}^{-1}$ & 0.9990 \\
\hline
\end{tabular}

Fig. 7 First and second-order adsorption kinetics for methyl orange adsorption on $\mathrm{BC}$ (open diamond) and $\mathrm{Fe}_{2} \mathrm{O}_{3}-\mathrm{BC}$ (filled diamond). Error bars indicate standard error of the mean

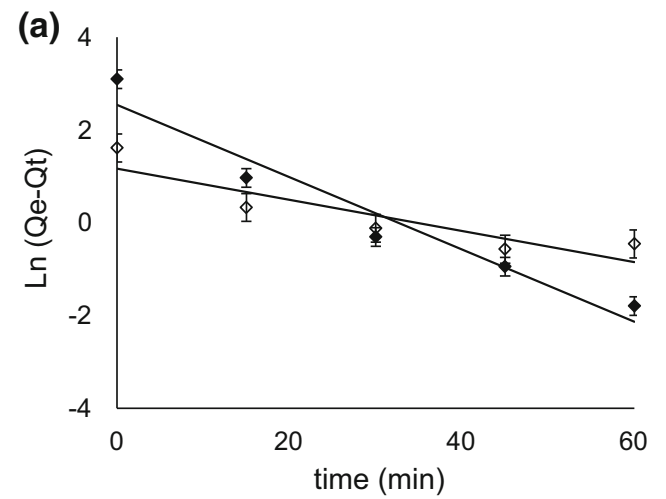

Table 3 Comparison of $\mathrm{BC}$ and $\mathrm{Fe}_{2} \mathrm{O}_{3}-\mathrm{BC}$ adsorbents with those from literature

\begin{tabular}{llllll}
\hline Adsorbent & Adsorbate & $Q_{e} \mathrm{mg} \mathrm{g}^{-1}$ & $\mathrm{pH}$ & $\mathrm{S}_{\mathrm{BET}}\left(\mathrm{m}^{2} \mathrm{~g}^{-1}\right)$ & Pore diameter $(\mathrm{nm})$ \\
\hline Coconut coir dust AC (Macedo et al. 2006) & $\mathrm{MB}$ & $12.89-13.75$ & $4-8$ & 1884 & $2-4$ \\
Banana peel (Bhattacharyya and Sharma 2005) & $\mathrm{MO}$ & 21 & 5.7 & $21-24$ & - \\
Orange peel (Bhattacharyya and Sharma 2005) & $\mathrm{MO}$ & 20.5 & 5.7 & $21-24$ & - \\
Humicola fuscoatra biomass (Subasioglu and Bilkay 2009) & $\mathrm{MO}$ & 0.5 & 5 & - & - \\
$\mathrm{BC}^{\mathrm{a}}$ & $\mathrm{MO}$ & 22.0 & 8 & 174 & $1.70-300$ \\
$\mathrm{Fe}_{2} \mathrm{O}_{3}-\mathrm{BC}^{\mathrm{a}}$ & $\mathrm{MO}$ & 46.6 & 3 & 15 & $1.70-300$ \\
\hline
\end{tabular}

${ }^{a}$ Results obtained in present work 
respectively. $\Delta G^{0}<0$ confirms the feasibility and spontaneity of adsorption, showing a high preference for MO to adsorb on both adsorbents (Pavlović et al. 2014). Comparable results were obtained in the adsorption of aniline by activated carbon- $\mathrm{Fe}_{3} \mathrm{O}_{4}$ nano-composite with $\Delta \mathrm{G}^{0}=-16.208 \mathrm{~kJ} \mathrm{~mol}^{-1}$ at $298 \mathrm{~K}$ (Kakavandi et al. 2013), and $-15.2051 \mathrm{~kJ} \mathrm{~mol}^{-1}$ for adsorption of methylene blue onto polymer- $\mathrm{Fe}_{3} \mathrm{O}_{4}$ nano-composite (Mittal et al. 2014).

\section{Conclusion}

This study indicates that the biochar and $\mathrm{Fe}_{2} \mathrm{O}_{3}$-biochar nano-composites prepared from paper pulp sludge can be used as an adsorbent for the treatment of wastewater containing MO. SEM and XRD analyses proved the iron oxide-biochar composites were nano-sized, although the BET surface areas were much lower than that of other biosorbents. In spite of this, the adsorption capacity of $\mathrm{Fe}_{2} \mathrm{O}_{3}-\mathrm{BC}$ was higher than that of coconut dust activated carbon, for example. $\mathrm{Fe}_{2} \mathrm{O}_{3}-\mathrm{BC}$ composite was more effective in removing $\mathrm{MO}$ at the maximum dye concentration and at the optimum adsorbent dosage. Examination of the adsorption isotherms revealed that the adsorption is well described by both the Langmuir and Freundlich models for both adsorbents. Kinetic studies indicate that adsorption data obeyed pseudosecond-order model. Free energy calculations showed feasibility of $\mathrm{MO}$ adsorption on the adsorbents was in the order: $\mathrm{Fe}_{2} \mathrm{O}_{3}-\mathrm{BC}>\mathrm{BC}$. Overall, the results show that $\mathrm{BC}$ and $\mathrm{Fe}_{2} \mathrm{O}_{3}-\mathrm{BC}$ derived from PPS are effective MO adsorbents, suggesting that they can be used for dye removal while minimising public health and environmental impacts associated with current PPS disposal practices. Further research should include scaling up to a pilot study to better establish the efficacy of the adsorbents, evaluating the residual concentration of iron in treated water, regeneration capacity of the adsorbents and the effect of competition on the adsorption of different dyes.

Acknowledgments The authors would like to thank the Chemistry Department of the University of Johannesburg for access to SEM, XRD and BET instruments. We would also like to thank the editor and four anonymous reviewers for insightful comments.

Open Access This article is distributed under the terms of the Creative Commons Attribution 4.0 International License (http:// creativecommons.org/licenses/by/4.0/), which permits unrestricted use, distribution, and reproduction in any medium, provided you give appropriate credit to the original author(s) and the source, provide a link to the Creative Commons license, and indicate if changes were made.

\section{References}

Abd EL, Latif MM, Ibrahim AM (2009) Adsorption, kinetic and equilibrium studies on removal of basic dye from aqueous solutions using hydrolyzed oak sawdust. Desalination Water Treat 6:252-268

Akama E, Tong AJ, Ito M, Tanaka S (1999) The study of the partitioning mechanism of methyl orange in an aqueous twophase system. Talanta 48:1133-1137

Al-Degs YS, El-Barghouthi MI, El-Sheikh AH, Walker GM (2008) Effect of $\mathrm{pH}$, ionic strength, and temperature on adsorption behaviour of reactive dyes on activated carbon. Dyes Pigment 77:16-23

Alslaibi TM, Abustan I, Ahmad MA, Foul AA (2014) Preparation of activated carbon from olive stone waste: optimization study on the removal of $\mathrm{Cu}^{2+}, \mathrm{Cd}^{2+}, \mathrm{Ni}^{2+}, \mathrm{Pb}^{2+}, \mathrm{Fe}^{2+}$, and $\mathrm{Zn}^{2+}$ from aqueous solution using response surface methodology. J Dispers Sci Technol 35:913-925

Alslaibi TM, Abustan I, Ahmad MA, Foul AA (2015) Comparative studies on the olive stone activated carbon adsorption of $\mathrm{Zn}^{2+}$, $\mathrm{Ni}^{2+}$, and $\mathrm{Cd}^{2+}$ from synthetic wastewater. Desalination Water Treat 54:166-177

Amuda OS, Giwa AA, Bello IA (2007) Removal of heavy metals from industrial waste water using modified activated coconut shell carbon. Biochem Eng J 36:174-181

Angulo-Bejarano PI, Martínez-Cruz O, Paredes-Lopez O (2014) Phytochemical content, nutraceutical potential and biotechnological applications of an ancient Mexican plant: nopal Opuntia ficus-indica). Curr Nutr Food Sci 10:96-217

Annadurai G, Juang RS, Lee DJ (2002) Use of cellulose-based wastes for adsorption of dyes from aqueous solutions. J Hazard Mater 92:263-274

Azami M, Bahram M, Nouri S, Naseri A (2012) A central composite design for the optimization of the removal of the azo dye, methyl orange, from waste water using the Fenton reaction. J Serbian Chem Soc 77:235-246

Barka N, Abdennouri M, El Makhfouk M, Qourzal S (2013) Biosorption characteristics of cadmium and lead onto ecofriendly dried cactus (Opuntia ficus indica) cladodes. J Environ Chem Eng 1:144-149

Belaid KD, Kacha S, Kameche M, Derriche Z (2013) Adsorption kinetics of some textile dyes onto granular activated carbon. J Environ Chem Eng 1:496-503

Bhatnagar A, Jain AK (2005) A comparative adsorption study with different industrial wastes as adsorbents for the removal of cationic dyes from water. J Colloid Interface Sci 281:49-55

Bhatt AS, Sakaria PL, Vasudevan M, Pawar RR, Sudheesh N, Bajaj HC, Mody HM (2012) Adsorption of an anionic dye from aqueous medium by organoclays: equilibrium modeling, kinetic and thermodynamic exploration. RSC Adv 2:8663-8671

Bhattacharyya KG, Sharma A (2005) Kinetics and thermodynamics of methylene blue sorption on neem (azadirachta indica) leaf powder. Dyes Pigment 65:51-59

Chaukura N (2011) Sorption of Gases and Liquids by Polymers of Intrinsic Microporosity (PIMs). Thesis, University of Manchester, United Kingdom

Chen D, Chen J, Luan X, Ji H, Xia Z (2011) Characterization of anioncationic surfactants modified montmorillonite and its application for the removal of methyl orange. Chem Eng J 171:1150-1158

Chung KT, Fulk GE, Andrews AW (1981) Mutagenicity testing of some commonly used dyes. Appl Environ Microbiol 42:641-648

Ciolacu D, Ciolacu F, Popa VI (2011) Amorphous cellulosestructure and characterisation. Cell Chem Technol 45:13-21 
Crini G (2006) Non-conventional low-cost adsorbents for dye removal: a review. Bioresour Technol 97:1061-1085

Espino-Díaz M, De Jesús Ornelas-Paz J, Martínez-Tellez MA, Santillan C, Barbosa-Canovas GV, Zamudio-Flores PB, Olivas GI (2010) Development and characterization of edible films based on mucilage of Opuntia ficus-indica (L.). J Food Sci 75:347-352

Feng B, Bhatia SK, Barry JC (2003) Variation of the crystalline structure of coal char during gasification. Energy Fuels 17:744-754

Gadd GM (2009) Biosorption: critical review of scientific rationale, environmental importance and significance for pollution treatment. J Chem Technol Biotechnol 84:13-28

Gong R, Ye J, Dai W, Yan X, Hu J, Hu X, Li S, Huang H (2013) Adsorptive removal of methyl orange and methylene blue from aqueous solution with finger-citron-residue-based activated carbon. Ind Eng Chem Res 52:14297-14303

Goscianska J, Marciniak M, Pietrzak R (2014) Mesoporous carbons modified with lanthanum(III) chloride for methyl orange adsorption. Chem Eng J 247:258-264

Gwenzi W, Musarurwa T, Nyamugafata P, Chaukura N, Chaparadza A, Mbera S (2014) Adsorption of $\mathrm{Zn}^{2+}$ and $\mathrm{Ni}^{2+}$ in a binary aqueous solution by biosorbants derived from sawdust and water hyacinth (Eichhornia crassipes). Water Sci Technol 70:1419-1427

Haldorai Y, Shim J (2014) An efficient removal of methyl orange dye from aqueous solution by adsorption onto chitosan $/ \mathrm{MgO}$ composite: a novel reusable adsorbent. Appl Surf Sci 292:447-453

Haque E, Jun WJ, Jhung SH (2011) Adsorptive removal of methyl orange and methylene blue from aqueous solution with a metalorganic framework material, iron terephthalate (MOF-235). J Hazard Mater 185:507-511

Holzwarth U, Gibson N (2011) The Scherrer equation versus the 'Debye-Scherrer equation'. Nat Nanotechnol. doi:10.1038/ nnano.2011.145

Jain R, Sikarwar S (2008) Removal of hazardous dye congo red from waste material. J Hazard Mater 152:942-948

Jalil AA, Triwahyono S, Adam SH, Rahim ND, Aziz MAA, Hairom NHH, Razali NAM, Abidin MAZ, Mohamadiah MKA (2010) Adsorption of methyl orange from aqueous solution onto calcined Lapindo volcanic mud. J Hazard Mater 181:755-762

Kakavandi B, Jafari AJ, Kalantary RR, Nasseri S, Ameri A, Esrafily A (2013) Synthesis and properties of $\mathrm{Fe}_{3} \mathrm{O}_{4}$-activated carbon magnetic nanoparticles for removal of aniline from aqueous solution: equilibrium, kinetic and thermodynamic studies. Iran J Environ Health Sci Eng. doi:10.1186/1735-2746-10-19

Khalili NR, Campbell M, Sandi G, Golaś J (2000) Production of micro- and mesoporous activated carbon from paper mill sludge: I. Effect of zinc chloride activation. Carbon 38:1905-1915

Khattri SD, Singh MK (2009) Removal of malachite green from dye wastewater using neem sawdust by adsorption. J Hazard Mater 67:1089-1094

Liang S, Guo X, Feng N, Tian Q (2010) Isotherms, kinetics and thermodynamic studies of adsorption of $\mathrm{Cu}^{2+}$ from aqueous solutions by $\mathrm{Mg}^{2+} / \mathrm{K}^{+}$type orange peel adsorbent. J Hazard Mater 174:756-762

Ma J, Yu F, Zhou L, Jin L, Yang M, Luan J, Tang Y, Fan H, Yuan Z, Chen J (2012) Enhanced adsorptive removal of methyl orange and methylene blue from aqueous solution by alkali-activated multiwalled carbon nanotubes. Appl Mater Interfaces 4:5749-5760

Macedo JS, da Costa Júnior NB, Almeida LE, da Silva Vieira EF, Cestari AR, Gimenez IF, Carreño NLV, Barreto LS (2006) Kinetic and calorimetric study of the adsorption of dyes on mesoporous activated carbon prepared from coconut coir dust. J Colloid Interface Sci 298:515-522
Mahmoodian H, Moradi O, Shariatzadeha B, Salehf TA, Tyagi I, Maity A, Asif M, Gupta VK (2015) Enhanced removal of methyl orange from aqueous solutions by polyHEMA-chitosanMWCNT nano-composite. J Mol Liq 202:189-198

Meroufel B, Benali O, Benyahia M, Benmoussa Y, Zenasni MA (2013) Adsorptive removal of anionic dye from aqueous solutions by Algerian kaolin: characteristics, isotherm, kinetic and thermodynamic studies. J Mater Environ Sci 4:482-491

Mittal H, Mishra SB (2014) Gum ghatti and $\mathrm{Fe}_{3} \mathrm{O}_{4}$ magnetic nanoparticles based nanocomposites for the effective adsorption of rhodamine B. Carbohydr Polym 101:1255-1264

Mittal A, Malviya A, Kaur D, Mittal J, Kurup L (2007) Studies on the adsorption kinetics and isotherms for the removal and recovery of Methyl Orange from wastewaters using waste materials. J Hazard Mater 148:229-240

Mittal H, Ballav N, Mishra SB (2014) Gum ghatti and $\mathrm{Fe}_{3} \mathrm{O}_{4}$ magnetic nanoparticles based nanocomposites for the effective adsorption of methylene blue from aqueous solution. J Ind Eng Chem 20:2184-2192

Mohan D, Pittman CU Jr (2007) Arsenic removal from water/ wastewater using adsorbents-a critical review. J Harzad Mater 142:1-53

Mohan D, Sarswat A, Ok YS, Pittman CU Jr (2014) Organic and inorganic contaminants removal from water with biochar, a renewable, low cost and sustainable adsorbent-a critical review. Bioresour Technol 160:191-202

Osman HE, Bawdy RK, Ahmad HF (2010) Usage of some agricultural by-products in the removal of some heavy metals from industrial wastewater. J Phytol 2:51-62

Park D, Yun Y, Park JM (2010) The past, present, and future trends of biosorption. Biotechnol Bioprocess Eng 15:86-102

Pathania D, Sharma S, Singh P (2013) Removal of methylene blue by adsorption onto activated carbon developed from Ficus carica bast. Arab J Chem. doi:10.1016/j.arabjc.2013.04.021

Pavlović DM, Ćurkovic L, Blažek D, Župan J (2014) The sorption of sulfamethazine on soil samples: Isotherms and error analysis. Sci Total Environ 497-498:543-552

Pellera F, Giannis A, Anastasiadou K, Kalderis D, Pentari D, Gidarakos E (2011) Adsorption of $\mathrm{Cu}(\mathrm{II})$ ions from aqueous solutions using biochars prepared from agricultural by-products. J Environ Manag 96:35-42

Rahimi S, Moattari M, Rajabi L, Derakhshan AA, Keyhani M (2015) Iron oxide/hydroxide $(\alpha, \gamma-\mathrm{FeOOH})$ nanoparticles as high potential adsorbents for lead removal from polluted aquatic media. J Ind Eng Chem 23:33-43

Rita K (2012) Adsorption of yellow dye: acid yellow RR from its aqueous solution using two different samples of activated carbon by static batch method. Nat Sci 4:112-115

Ruziwa DT, Chaukura N, Gwenzi W, Pumure I (2015) Removal of $\mathrm{Zn}^{2+}$ and $\mathrm{Pb}^{2+}$ from water using sulphonated waste polystyrene. J Environ Chem Eng 3:2528-2537

Said A, Aly A, El-Wahab M, Soliman S, El-Hafez A, Helmey V, Goda M (2013) Application of modified bagasse as a biosorbent for reactive dyes removal from industrial wastewater. J Water Resour Prot 5:10-17

Subasioglu T, Bilkay IS (2009) Determination of biosorption conditions of methyl orange by Humicol fuscoatra. J Sci Ind Res 68:1075-1077

Sun D, Zhange Z, Wang M, Wu Y (2013) Adsorption of rective dyes on activated carbon developed from Enteromorpha prolifera. Am J Anal Chem 4:17-26

Vala RMK, Tichagwa L (2013) Enhancement of the adsorption of phenol red from wastewater onto clinoptilolite by modification with N-terminated siloxanes. Clays Clay Miner 61:532-540

Valderrama C, Barios JI, Caetano M, Farran A, Cortina JL (2010) Kinetic evaluation of phenol/aniline mixtures adsorption from 
aqueous solutions onto activated carbon and hyper cross linked polymeric resin (MN200). React Funct Polym 70:142-150

Wang S, Gao B, Zimmerman AR, Li Y, Ma L, Harris WG, Migliaccio KW (2015) Removal of arsenic by magnetic biochar prepared from pinewood and natural hematite. Bioresour Technol 175:391-395

Zhan H, Yang X, Wang C, Liang C, Wu M (2010) Multiple growth stages and their kinetic models of anatase nanoparticles under hydrothermal conditions. J Phys Chem C 114:14461-14466

Zhang M, Gao B, Yao Y, Xue Y, Inyang M (2012) Synthesis of porous $\mathrm{MgO}$-biochar nanocomposites for removal of phosphate and nitrate from aqueous solutions. Chem Eng J 210:26-32
Zhang M, Gao B, Varnoosfaderani S, Hebard A, Yao Y, Inyang M (2013a) Preparation and characterization of a novel magnetic biochar for arsenic removal. Bioresour Technol 130:457-462

Zhang P, Sun H, Yu L, Sun T (2013b) Adsorption and catalytic hydrolysis of carbaryl and atrazine on pig manure-derived biochars: impact of structural properties of biochars. J Hazard Mater 244:217-224

Zhuang X, Wan Y, Feng C, Shen Y, Zhao D (2009) Highly efficient adsorption of bulky dye molecules in wastewater on ordered mesoporous carbons. Chem Mater 21:706-716 